\title{
Synthesis of Polyamide Dendrons Bearing Pyridine Groups as Multiple Hydrogen Bonding Parts on the Periphery
}

\author{
Takayuki Kouketsu, Masa-aki KaKimoto, ${ }^{\dagger}$ Mitsutoshi JikeI, ${ }^{*}$ and Sang Youl KIM** \\ Department of Organic and Polymeric materials, Tokyo Institute of Technology, \\ 2-12-1, O-okayama, Meguro-ku, Tokyo 152-8552, Japan \\ *Department of Material-process Engineering and Applied Chemistry for Environments, Akita University, \\ 1-1, Tegata, Gakuen-machi, Akita 010-8502, Japan \\ ** Department of Chemistry, Korea Advanced Institute of Science and Technology, \\ 373-1, Kusong-dong, Yusong-gu, Taejon 305-701, Korea
}

(Received November 25, 2003; Accepted March 26, 2004; Published July 15, 2004)

\begin{abstract}
Aromatic polyamide dendrons (G0-G2) having amino groups on the periphery were prepared by divergent method. Reaction of G0 aromatic polyamide dendron with isonicotinoyl chloride hydrochloride gave polyamide dendron (G0-2Py) bearing two pyridine groups. The structures of polyamide dendrons were confirmed by IR, ${ }^{1} \mathrm{H},{ }^{13} \mathrm{C}$ NMR, MALDI-TOF mass spectroscopy. A hydrogen-bonded G0-2Py/poly(acrylic acid) (PAA) 1/2 complex was prepared by mixing G0-2Py with PAA in methanol, followed by removing the solvent. IR spectrum of G0-2Py/ PAA $1 / 2$ complex showed characteristic absorptions at 2550 and $1950 \mathrm{~cm}^{-1}$ due to hydrogen bonding. A glass transition temperature $\left(T_{\mathrm{g}}\right)$ of G0-2Py/PAA $1 / 2$ complex was observed at $121^{\circ} \mathrm{C}$ by DSC measurement, whereas $T_{\mathrm{g}} \mathrm{s}$ of G0-2Py $\left(137^{\circ} \mathrm{C}\right)$ and PAA $\left(87^{\circ} \mathrm{C}\right)$ disappeared. $T_{\mathrm{g}}$ of the G0-2Py/PAA complex was dependent on the molar ratio ([Donor]/[Acceptor]). Maximum $T_{\mathrm{g}}$ at $121^{\circ} \mathrm{C}$ was observed at a ratio of 1. [DOI 10.1295/polymj.36.513] KEY WORDS Polyamide Dendron / Pyridine Group / Multiple Hydrogen Bonding /
\end{abstract}

Self-assembly based on selective control of non-covalent interactions provides a powerful tool for the creation of structured systems at the molecular level. Hydrogen bonding is one of the important non-covalent interactions in nature because of its stability, dynamics, and directionality. Meijer and co-workers recently reported stable complexes formed by quadruple hydrogen bonding between 2-ureido- $4[1 H]$-pyrimidone (UPy) units attached to various spacers. ${ }^{1-4}$ Self-assembled molecules containing multiple hydrogen bonding units exhibited polymer-like properties such as shear thinning in the melt phase, viscoelastic behavior in the solid state, and glass transition temperatures. Initial supramolecular systems based on multiple hydrogen bonding were reported by Lehn, ${ }^{5}$ Kato and Fréchet, ${ }^{6-8}$ and Whitesides.9-12 These diverse efforts focused on the selective formation of discrete supramolecules from complementary receptor-substrate hydrogen bonding pairs, such as barbituric acid and triaminopyrimidine units, 2,6-diaminopyridine and 2,6-pyridinedicarbonyl units, and carboxylic acid and pyridine units.

Dendritic macromolecules such as dendrimers and hyperbranched polymers have received much attention in recent years. These polymers have unique properties such as low viscosity, high solubility, amorphous nature, and multi-functionality, due to unique architecture. In particular, dendrimers have well-controllable structure and size with perfect branching.
Number of functional groups on the periphery of dendrimers can be controlled precisely by the number of generations. Tomalia and co-workers ${ }^{13-15}$ and Kabanov et al. ${ }^{16,17}$ reported polyion complexes formed by DNA and poly(amideamine) starburst dendrimers or Astramol poly(propyleneimine) dendrimers. These complexes could be used in gene delivery strategies or interpolyelectrolyte complexes. Zhang et al. recently reported the formation of a microporous film by alternating the deposition of poly(4-vinylpyridine) and carboxyl-terminated polyether dendrimers via hydrogen bonding in a cyclic fashion. ${ }^{18}$ Using the ends of dendrimers for multiple hydrogen bonding expects obtaining a stable complex.

Previously, we reported the preparation and properties of complexes between polyamide dendrons bearing carboxyl groups as hydrogen bonded donors and poly(4-vinylpyridine) as hydrogen bonded acceptor. ${ }^{19}$ Polyamide dendrons having carboxyl groups on the periphery were mixed with poly(4-vinylpyridine) to form complexes via multiple hydrogen bonding. It was found that complexes were obtained by DSC and ${ }^{1} \mathrm{H}$ NMR spin-lattice relaxation time $\left(T_{1}\right)$ measurements. This paper reports the synthesis of various polyamide dendrons bearing pyridine groups as hydrogen bonded acceptors, and the preparation of the complexes from these dendrons and poly(acrylic acid) via multiple hydrogen bonding. 


\section{EXPERIMENTAL}

\section{Materials}

3,5-Dinitrobenzoyl chloride (DNBC) was used as received from Tokyo Chemical Industry Co., Ltd. 1,3-Phenylenediamine ( $m$-PD), isonicotinoyl chloride hydrochloride (INC), and poly(acrylic acid) $\left(M_{\mathrm{w}}=\right.$ 2000) were used as received from Aldrich. N,N-Dimethylacetoamide (DMAc) was purified by vacuum distillation over calcium hydride. Methanol and $10 \%$ palladium on activated carbon $(\mathrm{Pd}-\mathrm{C})$ were used as received.

G1-4NO $\mathrm{N}_{2}$. In a flask equipped with a magnetic stirrer and nitrogen inlet were placed 1,3-phenylenediamine $(2.16 \mathrm{~g}, 20.0 \mathrm{mmol})$ and DMAc $(150 \mathrm{~mL}) .3,5-$ Dinitrobenzoyl chloride $(11.1 \mathrm{~g}, 48 \mathrm{mmol})$ was added. The solution was stirred at room temperature for $3 \mathrm{~h}$. The reaction mixture was then poured into water. The crude product was filtered and washed with hot methanol. The product was filtered and dried at $80{ }^{\circ} \mathrm{C}$ in vacuo. The yield was $99 \%$. ${ }^{1} \mathrm{H}$ NMR (DMSO- $\left.d_{6}\right): \delta 10.94(\mathrm{~s}, 2 \mathrm{H}$, amide $\mathrm{H}), 9.18(\mathrm{~s}, 4 \mathrm{H})$, $9.00(\mathrm{~s}, 2 \mathrm{H}), 8.40(\mathrm{~s}, 1 \mathrm{H}), 7.57(\mathrm{~d}, 2 \mathrm{H}), 7.42(\mathrm{t}, 1 \mathrm{H})$.

$\mathrm{Gl}-4 \mathrm{NH}_{2}$. In a flask equipped with a magnetic stirrer and hydrogen inlet were placed G1-4NO $2(1.99 \mathrm{~g}$, $4.0 \mathrm{mmol})$, DMAc $(120 \mathrm{~mL})$, and $10 \% \mathrm{Pd}-\mathrm{C}(0.851 \mathrm{~g}$, $5 \mathrm{~mol} \%)$. The flask was degassed and purged with hydrogen several times and then stirred at room temperature for $2 \mathrm{~d}$. The mixture was filtered using Celite545. The solution was concentrated and poured into $\mathrm{CH}_{2} \mathrm{Cl}_{2}$. The product was filtered and dried at $50^{\circ} \mathrm{C}$ in vacuo. The yield was $92 \% .{ }^{1} \mathrm{H}$ NMR (DMSO- $d_{6}$ ): $\delta 9.91(\mathrm{~s}, 2 \mathrm{H}$, amide $\mathrm{H}), 8.18(\mathrm{~s}, 1 \mathrm{H}), 7.37(\mathrm{~d}, 2 \mathrm{H})$, $7.20(\mathrm{t}, 1 \mathrm{H}), 6.28(\mathrm{~s}, 4 \mathrm{H}), 5.98(\mathrm{~s}, 2 \mathrm{H}), 4.93$ (s, 8H, $\mathrm{NH}_{2}$ ).

$G 2-8 \mathrm{NO}_{2}$. In a flask equipped with a magnetic stirrer and nitrogen inlet were placed G1-4NH $2(0.565 \mathrm{~g}$, $1.5 \mathrm{mmol})$ and DMAc (15 mL). 3,5-Dinitrobenzoyl chloride $(2.08 \mathrm{~g}, 9.0 \mathrm{mmol})$ was added. The solution was stirred at room temperature for $12 \mathrm{~h}$. The reaction mixture was then poured into water. The crude product was filtered and washed with hot methanol. The product was filtered and dried at $80{ }^{\circ} \mathrm{C}$ in vacuo. The yield was 95\%. ${ }^{1} \mathrm{H}$ NMR (DMSO- $d_{6}$ ): $\delta 11.15$ (s, 4H, amide $\mathrm{H}), 10.51$ (s, 2H, amide $\mathrm{H}), 9.23$ (s, $8 \mathrm{H}), 9.03$ (s, 4H), $8.71(\mathrm{~s}, 2 \mathrm{H}), 8.34(\mathrm{~s}, 1 \mathrm{H}), 8.11$ (s, $4 \mathrm{H}), 7.52(\mathrm{~d}, 2 \mathrm{H}), 7.32(\mathrm{t}, 1 \mathrm{H})$.

$G 2-8 \mathrm{NH}_{2}$. In a flask equipped with a magnetic stirrer and hydrogen inlet were placed $\mathrm{G} 2-8 \mathrm{NO}_{2}(1.50 \mathrm{~g}$, $1.3 \mathrm{mmol}), \mathrm{DMAc}(100 \mathrm{~mL})$, and $10 \% \mathrm{Pd}-\mathrm{C}(0.553 \mathrm{~g}$, $5 \mathrm{~mol} \%)$. The flask was degassed and purged with hydrogen several times and then stirred at room temperature for $2 \mathrm{~d}$. The mixture was filtered using Celite545. The solution was concentrated and poured into
$\mathrm{CH}_{2} \mathrm{Cl}_{2}$. The product was filtered and dried at $50^{\circ} \mathrm{C}$ in vacuo. The yield was $81 \% .{ }^{1} \mathrm{H}$ NMR (DMSO- $d_{6}$ ): $\delta 10.35(\mathrm{~s}, 2 \mathrm{H}$, amide $\mathrm{H}), 10.13(\mathrm{~s}, 4 \mathrm{H}$, amide $\mathrm{H})$, $8.38(\mathrm{~s}, 2 \mathrm{H}), 8.29(\mathrm{~s}, 1 \mathrm{H}), 7.91(\mathrm{~s}, 4 \mathrm{H}), 7.49(\mathrm{~d}$, $2 \mathrm{H}), 7.30(\mathrm{t}, 1 \mathrm{H}), 6.33(\mathrm{~s}, 8 \mathrm{H}), 6.00(\mathrm{~s}, 4 \mathrm{H}), 4.95$ (s, $16 \mathrm{H}, \mathrm{NH}_{2}$ ).

G0-2Py. In a flask equipped with a magnetic stirrer and nitrogen inlet were placed 1,3-phenylenediamine $(2.16 \mathrm{~g}, 20.0 \mathrm{mmol})$ and DMAc $(100 \mathrm{~mL})$. Isonicotinoyl chloride hydrochloride $(8.54 \mathrm{~g}, 48 \mathrm{mmol})$ was added. The solution was stirred at room temperature for $3 \mathrm{~h}$. The solution was then poured into dilute $\mathrm{NaOH}$ water. The product was filtered and dried at $80^{\circ} \mathrm{C}$ in vacuo. The yield was $94 \%$. IR ( $\mathrm{KBr}$, $\mathrm{cm}^{-1}$ ): 1687, 1615, 1556, 1440. ${ }^{1} \mathrm{H}$ NMR (DMSO$\left.d_{6}\right): \delta 10.58(\mathrm{~s}, 2 \mathrm{H}$, amide $\mathrm{H}), 8.78(\mathrm{~d}, 4 \mathrm{H}), 8.35(\mathrm{~s}$, $1 \mathrm{H}), 7.86(\mathrm{~d}, 4 \mathrm{H}), 7.52(\mathrm{~d}, 2 \mathrm{H}), 7.36(\mathrm{t}, 1 \mathrm{H}) .{ }^{13} \mathrm{C} \mathrm{NMR}$ $\left(\mathrm{DMSO}-d_{6}\right): \delta$ 164.1, 150.3, 141.9, 138.9, 128.9, 121.7, 116.6, 112.9. MALDI-TOF MS: $\mathrm{m} / \mathrm{z}$ calcd for $\mathrm{C}_{18} \mathrm{H}_{14} \mathrm{~N}_{4} \mathrm{O}_{2} \quad 319.3\left(\mathrm{M}+\mathrm{H}^{+}\right)$, found 319.9 $\left(\mathrm{M}+\mathrm{H}^{+}\right)$.

G1-4Py. In a flask equipped with a magnetic stirrer and nitrogen inlet were placed $\mathrm{G} 1-4 \mathrm{NH}_{2}(0.753 \mathrm{~g}$, $2.0 \mathrm{mmol})$ and DMAc $(20 \mathrm{~mL})$. Isonicotinoyl chloride hydrochloride $(1.71 \mathrm{~g}, 9.6 \mathrm{mmol})$ was added. The solution was stirred at room temperature for $3 \mathrm{~h}$. The solution was then poured into dilute $\mathrm{NaOH}$ water. The product was filtered and dried at $80^{\circ} \mathrm{C}$ in vacuo. The yield was $90 \%$. IR $\left(\mathrm{KBr}, \mathrm{cm}^{-1}\right)$ : 1664, 1605, 1553, 1447. ${ }^{1} \mathrm{H}$ NMR (DMSO- $\left.d_{6}\right): \delta 10.82(\mathrm{~s}, 4 \mathrm{H}$, amide $\mathrm{H}), 10.47(\mathrm{~s}, 2 \mathrm{H}$, amide $\mathrm{H}), 8.81(\mathrm{~d}, 8 \mathrm{H})$, $8.60(\mathrm{~s}, 2 \mathrm{H}), 8.32(\mathrm{~s}, 1 \mathrm{H}), 8.07(\mathrm{~s}, 4 \mathrm{H}), 7.92(\mathrm{~d}$, $8 \mathrm{H}), 7.50(\mathrm{~d}, 2 \mathrm{H}), 7.33(\mathrm{t}, 1 \mathrm{H}) .{ }^{13} \mathrm{C}$ NMR (DMSO$\left.d_{6}\right): \delta 165.7,164.3,150.4,141.7,139.4,139.0$, $136.4,128.8,121.7,116.1,116.0,115.6,112.8$. MALDI-TOF MS: $m / z$ calcd for $\mathrm{C}_{44} \mathrm{H}_{32} \mathrm{~N}_{10} \mathrm{O}_{6} 819.7$ $\left(\mathrm{M}+\mathrm{Na}^{+}\right)$, found $820.3\left(\mathrm{M}+\mathrm{Na}^{+}\right)$.

$G 2-8 P y$. In a flask equipped with a magnetic stirrer and nitrogen inlet were placed $\mathrm{G} 1-4 \mathrm{NH}_{2}(0.456 \mathrm{~g}$, $0.5 \mathrm{mmol})$ and DMAc $(10 \mathrm{~mL})$. Isonicotinoyl chloride hydrochloride $(1.07 \mathrm{~g}, 6.0 \mathrm{mmol})$ was added. The solution was stirred at room temperature for $3 \mathrm{~h}$. The solution was then poured into dilute $\mathrm{NaOH}$ water. The product was filtered and dried at $80^{\circ} \mathrm{C}$ in vacuo. The yield was $87 \%$. IR $\left(\mathrm{KBr}, \mathrm{cm}^{-1}\right)$ : 1665,1605 , 1553, 1448. ${ }^{1} \mathrm{H}$ NMR (DMSO- $\left.d_{6}\right): \delta 10.82(\mathrm{~s}, 8 \mathrm{H}$, amide $\mathrm{H}$ ), 10.68 (s, 4H, amide $\mathrm{H}$ ), 10.46 (s, 2H, amide $\mathrm{H}), 8.80(\mathrm{~d}, 16 \mathrm{H}), 8.58(\mathrm{~s}, 4 \mathrm{H}), 8.53(\mathrm{~s}, 2 \mathrm{H}), 8.35$ (s, $1 \mathrm{H}), 8.13(\mathrm{~s}, 8 \mathrm{H}), 8.03(\mathrm{~s}, 4 \mathrm{H}), 7.91(\mathrm{~d}, 16 \mathrm{H}), 7.50(\mathrm{~d}$, $2 \mathrm{H}), 7.32(\mathrm{t}, 1 \mathrm{H}) .{ }^{13} \mathrm{C}$ NMR (DMSO- $\left.d_{6}\right): \delta$ 170.0, $166.2,166.1,164.5,150.5,141.8,139.6,139.5$, $139.2,136.6,136.3,128.9,121.8,116.2,116.0$, 115.7, 112.9. MALDI-TOF MS: $\mathrm{m} / \mathrm{z}$ calcd for $\mathrm{C}_{96} \mathrm{H}_{68} \mathrm{~N}_{22} \mathrm{O}_{14} \quad 1776.7 \quad\left(\mathrm{M}+\mathrm{Na}^{+}\right)$, found 1778.7 $\left(\mathrm{M}+\mathrm{Na}^{+}\right)$. 
Preparation of Polyamide Dendron/PAA Complexes

The polyamide dendron/PAA complexes were prepared by evaporation from methanol or DMAc solution containing equimolar amounts of hydrogen bonding acceptor and donor moieties followed by drying in vacuo at $60^{\circ} \mathrm{C}$. For example, the G1-4Py/PAA $1 / 4$ complex (i.e. donor/acceptor $=1 / 1$ ) was prepared by the mixture of G1-4Py $(0.0398 \mathrm{~g}, 0.05 \mathrm{mmol})$ and PAA $(0.0144 \mathrm{~g}, 0.2 \mathrm{mmol})$ in DMAc $(50 \mathrm{~mL})$, followed by drying in vacuo at $60^{\circ} \mathrm{C}$ after it was concentrated DMAc.

\section{Measurements}

IR spectra were recorded on a Bomem Michelson series FT-IR spectrometer. ${ }^{1} \mathrm{H}$ and ${ }^{13} \mathrm{C}$ NMR spectroscopic measurements were carried out on $300 \mathrm{MHz}$ Bruker NMR spectrometers. Thermogravimetric analysis (TGA) and differential scanning calorimetry (DSC) were performed at a heating rate of $10^{\circ} \mathrm{C} /$ min under nitrogen on a TA 2200 thermal analyzer system, $T_{\mathrm{g}}$ was taken at the middle of the step transition in the second heating run.

\section{RESULTS AND DISCUSSION}

\section{Synthesis of Polyamide Dendrons}

The synthetic routes for aromatic polyamide dendrons are shown in Scheme $1 .{ }^{20} \mathrm{G} 1-4 \mathrm{NH}_{2}$ was prepared by the hydrogenation of G1-4NO $\mathrm{N}_{2}$ synthesized from 1,3-phenylenediamine and 3,5-dinitrobenzoyl chloride. The crude G1-4NO $\mathrm{Na}_{2}$ was washed with hot methanol in order to remove excess 3,5-dinitrobenzo$\mathrm{yl}$ chloride and its hydrate. The structure of $\mathrm{G} 1-4 \mathrm{NO}_{2}$ was confirmed by ${ }^{1} \mathrm{H}$ NMR. G2-8 $\mathrm{NH}_{2}$ was also prepared by the hydrogenation of $\mathrm{G} 2-8 \mathrm{NO}_{2}$ prepared from G1-4 $\mathrm{NH}_{2}$ and 3,5-dinitrobenzoyl chloride. The reaction of $\mathrm{G} 1-4 \mathrm{NH}_{2}$ or $\mathrm{G} 2-8 \mathrm{NH}_{2}$ with isonicotinoyl chloride hydrochloride (INC) was carried out at room temperature for $3 \mathrm{~h}$ in DMAc to give G1-4Py and G28 Py bearing four and eight pyridine groups on the periphery. G0-2Py bearing two pyridine groups at the end was prepared by reaction of 1,3-phenylenediamine with INC. The structure of aromatic polyamide dendrons was confirmed by IR, ${ }^{1} \mathrm{H},{ }^{13} \mathrm{C} \mathrm{NMR}$, and MALDI-TOF mass spectroscopies. Because the starting materials, 1,3-phenylenediamine, G1-4 $\mathrm{NH}_{2}$, and $\mathrm{G} 2-8 \mathrm{NH}_{2}$, can be isolated without column chromatography, these dendrons can be synthesized readily on a large scale.

Solubility of aromatic polyamide dendrons are shown in Table I. The aromatic polyamide dendrons bearing pyridine groups on the periphery were soluble in aprotic polar solvents, such as DMF, DMAc, NMP, and DMSO. G0-2Py was also soluble in methanol. Aromatic polyamide dendrons were also partially soluble in $\mathrm{HCl}$ water due to pyridine groups of the dendrons.

Thermal properties of dendrons were examined by TGA and DSC (Table II). Although the molecular weight of G1-4Py is $797 \mathrm{~g} / \mathrm{mol}$, it has a high glass transition temperature $\left(T_{\mathrm{g}}\right)$ of $219^{\circ} \mathrm{C}$ at second scan quenching with liquid nitrogen. $T_{\mathrm{g}}$ was dependent on the generation number of dendrons and increased to $263^{\circ} \mathrm{C}$ for G2-8Py. DSC curves of G1-4Py showed an endothermic peak of $215^{\circ} \mathrm{C}$ and an exothermic peak of $272{ }^{\circ} \mathrm{C}$ (Figure 2). It suggests that the endothermic peak was the $T_{\mathrm{g}}$, and the exothermic peak was crystallization. The melting point of G1-4Py was observed at $360^{\circ} \mathrm{C}$ by DTA measurement. In the case of G0-2Py and G2-8Py, properties similar

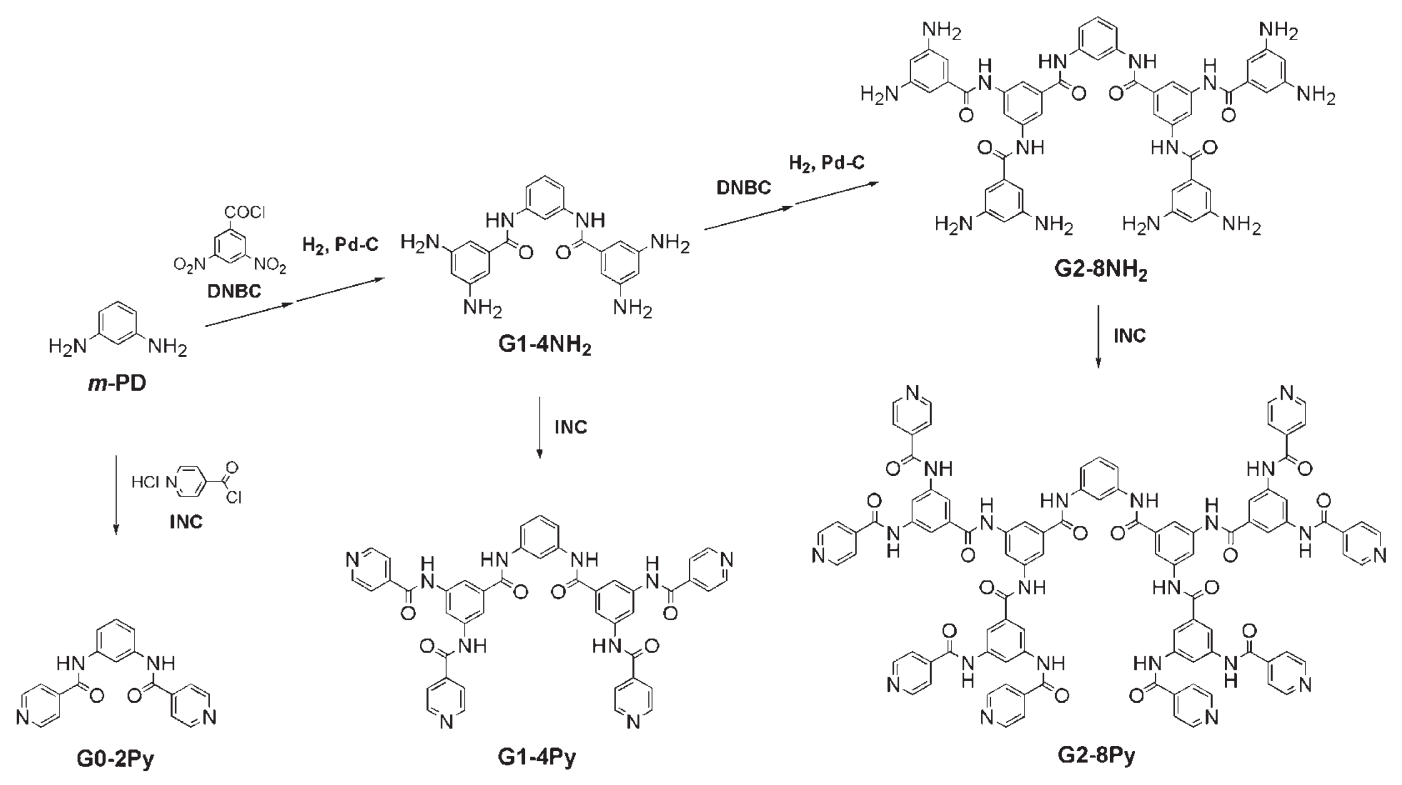

Scheme 1. Synthesis of aromatic polyamide dendrons bearing pyridine groups. 


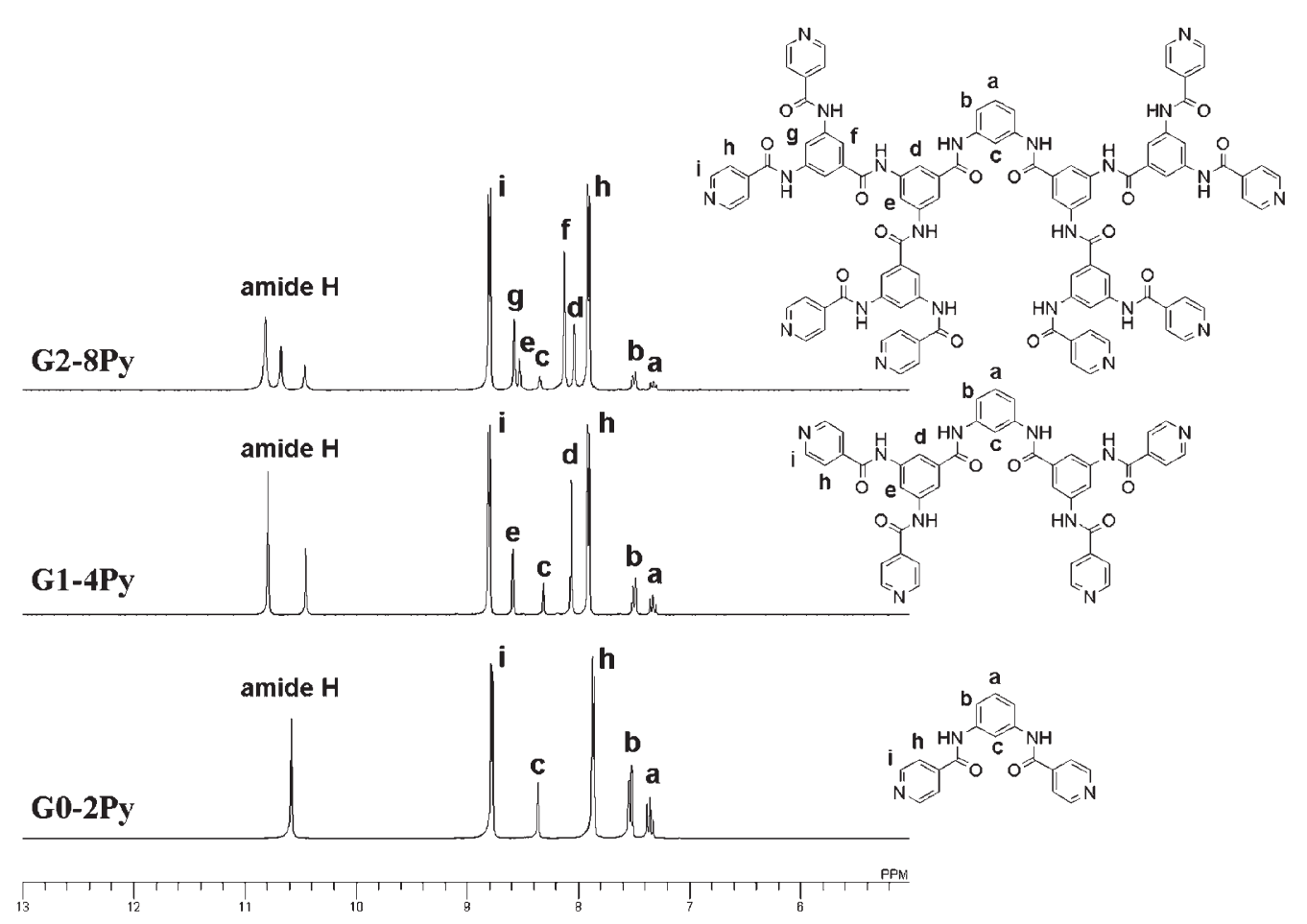

Figure 1. ${ }^{1} \mathrm{H}$ NMR spectra of aromatic polyamide dendrons; (a) G0-2Py, (b) G1-4Py, (c) G2-8Py.

Table I. Solubility of Polyamide Dendrons ${ }^{\mathrm{a}}$

\begin{tabular}{lcccc}
\hline & G0-2Py & G1-4Py & G2-8Py & PAA \\
\hline$n$-Hexane & - & - & - & - \\
Acetone & - & - & - & - \\
$\mathrm{MeOH}$ & ++ & - & - & ++ \\
EtOAc & - & - & - & - \\
$\mathrm{THF}$ & - & - & - & ++ \\
$\mathrm{CHCl}_{3}$ & - & - & - & - \\
$\mathrm{CH}_{2} \mathrm{Cl}_{2}$ & - & - & - & - \\
$\mathrm{H}_{2} \mathrm{O}$ & - & - & - & ++ \\
aq HCl & ++ & +- & +- & ++ \\
DMAc & ++ & ++ & ++ & ++ \\
DMSO & ++ & ++ & ++ & ++ \\
\hline
\end{tabular}

a ++ : soluble, +- : partially soluble, - : insoluble

to the case of G1-4Py were not observed. Thermal decomposition temperature $\left(T_{\mathrm{d}}\right)$ of G0-2Py, G1-4Py and G2-8Py was more than $300^{\circ} \mathrm{C}$.

\section{PREPARATION AND PROPERTIES OF POLY- AMIDE DENDRON/PAA COMPLEXES}

The pyridine groups of polyamide dendrons are hydrogen bonding acceptor, and carboxyl groups of poly(acrylic acid) (PAA) $\left(M_{\mathrm{w}}=2000\right)$ are hydrogen bonding donor. The complexes were prepared by mixing polyamide dendrons with PAA in methanol or DMAc. A powdery complex was isolated after removing methanol or DMAc used as solvent, as described in Scheme 2. The IR spectrum of G0-2Py/PAA $1 / 2$ $(1 / 2=$ molar ratio, i.e. $[$ Donor $] /[$ Acceptor $]=1 / 1)$
Table II. Thermal Properties of Polyamide Dendrons

\begin{tabular}{lccc}
\hline Formula weight & $\begin{array}{c}T_{\mathrm{g}}{ }^{\mathrm{a}} \\
\left({ }^{\circ} \mathrm{C}\right)\end{array}$ & $\begin{array}{c}T_{\mathrm{d}}{ }^{\mathrm{b}} \\
\left({ }^{\circ} \mathrm{C}\right)\end{array}$ \\
\hline G0-2Py & 318.33 & 137 & 333 \\
G1-4Py & 796.79 & 219 & 390 \\
G2-8Py & 1753.71 & 263 & 411 \\
\hline
\end{tabular}

${ }^{\text {a }}$ Determined by DSC at a heating rate of $10^{\circ} \mathrm{C} / \mathrm{min}$ in $\mathrm{N}_{2}$ (second scan). ${ }^{\mathrm{b}}$ Determined by TGA at a heating rate of $10^{\circ} \mathrm{C} / \mathrm{min}$ in $\mathrm{N}_{2}$.

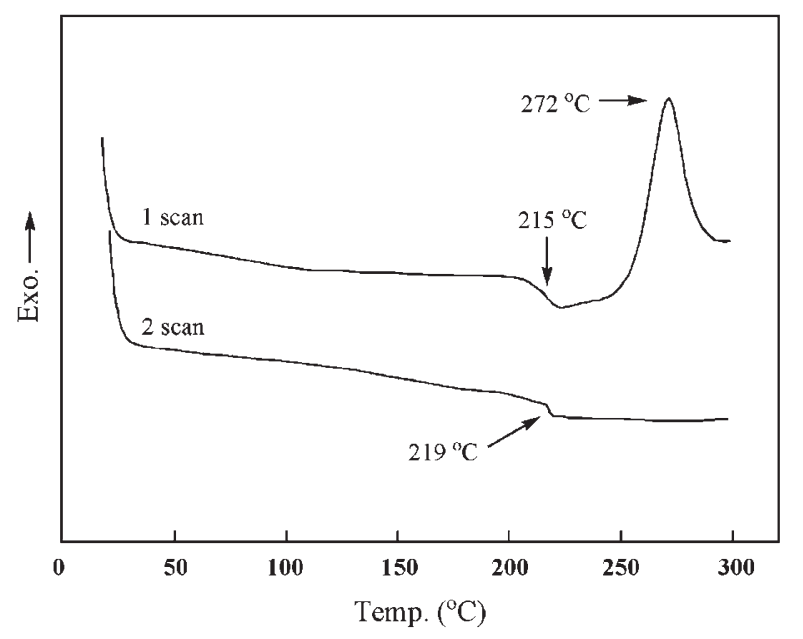

Figure 2. DSC curves of G1-4Py. Determined by DSC at a heating rate of $10^{\circ} \mathrm{C} / \mathrm{min}$ in $\mathrm{N}_{2}$.

complex showed characteristic absorptions at 2550 and $1950 \mathrm{~cm}^{-1}$ due to the hydrogen bond as shown in Figure $3 .^{6-8}$ Absorption attributed to the stretching 


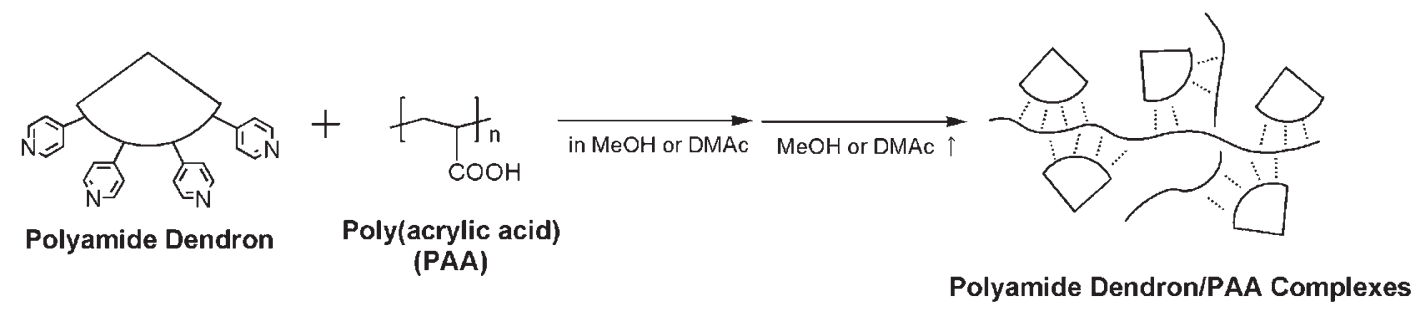

Scheme 2. Preparation of polyamide dendron/PAA complexes.

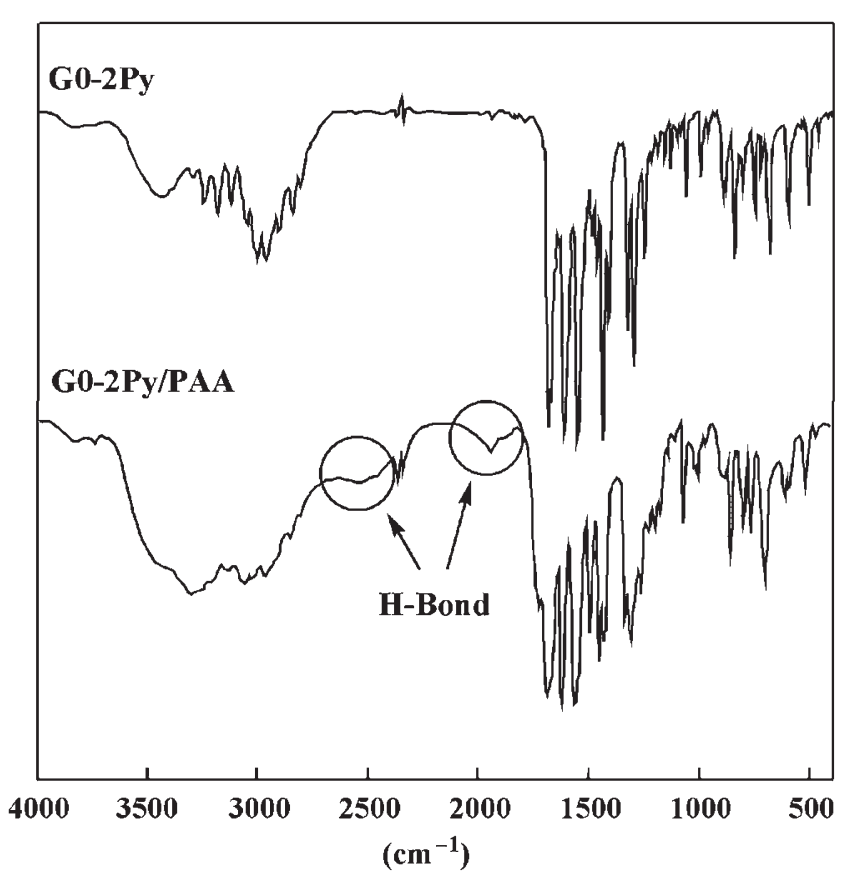

Figure 3. IR spectra of G0-2Py (a) and G0-2Py/PAA 1/1 complex (b).

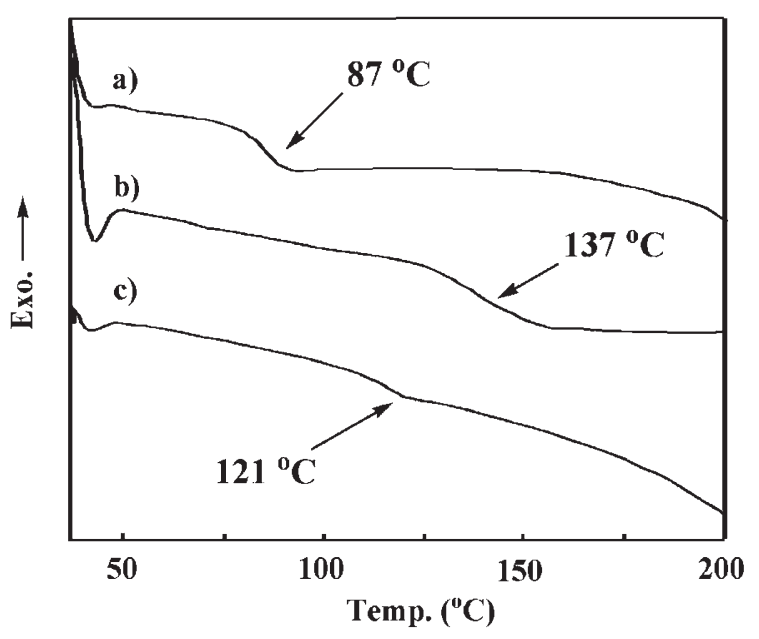

Figure 4. DSC curves of PAA (a), G0-2Py (b), and G0-2Py/ PAA $1 / 2$ complex (c). Determined by DSC at a heating rate of $10^{\circ} \mathrm{C} / \mathrm{min}$ in $\mathrm{N}_{2}$ (second scan).

mode of pyridine ring also shifted from 997 to $1015 \mathrm{~cm}^{-1}$. Other peaks such as amide bond of dendrons and carboxyl group of PAA did not change.
Table III. Relationship between $T_{\mathrm{g}}$ and PAA Content in G0-2Py/PAA Complex

\begin{tabular}{cc}
\hline [Donor]/[Acceptor] & $T_{\mathrm{g}}\left({ }^{\circ} \mathrm{C}\right)^{\mathrm{a}}$ \\
\hline 0.5 & 113 \\
0.75 & 118 \\
1 & 121 \\
1.25 & 117 \\
1.5 & 113 \\
2 & 113 \\
3 & 109 \\
5 & 110 \\
10 & 101 \\
\hline
\end{tabular}

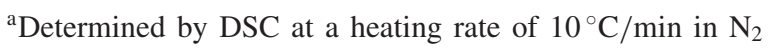
(second scan).

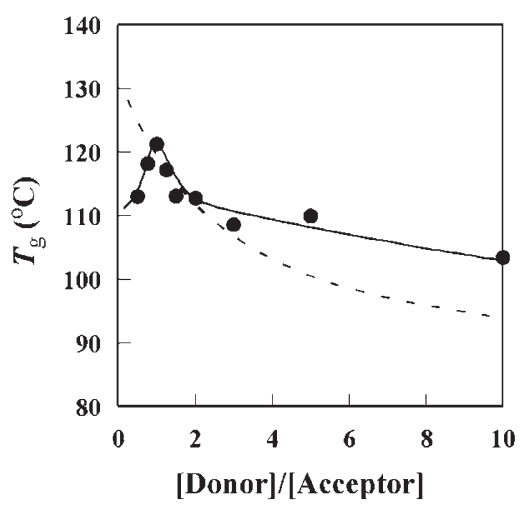

Figure 5. Effects of the donor/acceptor ratio of dendrons and PAA on $T_{\mathrm{g}}$ of a complex. The broken line (-- -) is determined by Fox equation $\left(1 / T_{\mathrm{g}}=w_{1} / T_{\mathrm{g} 1}+w_{2} / T_{\mathrm{g} 2}\right)$.

DSC curves of G0-2Py, PAA, and its complex are shown in Figure 4. A single new $T_{\mathrm{g}}$ of $\mathrm{G} 0-2 \mathrm{Py} /$ PAA $1 / 2$ complex was observed at $121^{\circ} \mathrm{C}$ as a single peak by DSC measurement, whereas $T_{\mathrm{g}}$ of G0-2Py at $137^{\circ} \mathrm{C}$ and $T_{\mathrm{g}}$ of PAA at $87^{\circ} \mathrm{C}$ disappeared. This suggests that G0-2Py and PAA are miscible. G1-4Py/ PAA $1 / 4$ and G2-8Py/PAA 1/8 complexes were prepared, and the IR spectrum of G1-4Py/PAA and G28Py/PAA complex showed characteristic absorption due to the hydrogen bonding. $T_{\mathrm{g}} \mathrm{s}$ of G1-4Py/PAA $1 / 4$ and G2-8Py/PAA $1 / 8$ complexes were not observed at $30^{\circ} \mathrm{C}$ to $200^{\circ} \mathrm{C}$. $T_{\mathrm{g}}$ s of complexes may be higher than $217^{\circ} \mathrm{C}$ which is an onset thermal degradation temperature of PAA. 
$T_{\mathrm{g}} \mathrm{s}$ of $\mathrm{G} 0-2 \mathrm{Py} / \mathrm{PAA}$ were dependent on the ratio of [Donor]/[Acceptor] as shown in Table III and Figure 5. Maximum $T_{\mathrm{g}}$ at $121^{\circ} \mathrm{C}$ was observed when the ratio was 1 . It suggests that the maximum complex was obtained because of the formation of a strong network. $T_{\mathrm{g}}$ of the G0-2Py/PAA complex decreased with increase of the ratio. According to the Fox equation, ${ }^{21}$ $T_{\mathrm{g}}$ of the complex decreases with increase of the PAA ratio. As shown in Figure 5, $T_{\mathrm{g}}$ s of the G0-2Py/PAA complexes were higher than that of the Fox equation (broken line). This can be explained by multiple hydrogen bonding. Formation of hydrogen bonding suggests that the mobility of PAA decreases.

\section{CONCLUSIONS}

Aromatic polyamide dendrons bearing pyridine groups on the periphery were synthesized by the divergent method. The dendrons were mixed poly(acrylic acid) (PAA) to form complexes via multiple hydrogen bonding. IR spectra of G0-2Py/PAA, G1-4Py/ PAA, and G2-8Py/PAA complexes suggested the formation of hydrogen bondings. A new $T_{\mathrm{g}}$ was observed for each complex and $T_{\mathrm{g}}$ was dependent on the molar ratio of the dendron and PAA. Maximum $T_{\mathrm{g}}$ at $121^{\circ} \mathrm{C}$ was observed when donor (PAA) and acceptor (G02Py) ratio was 1. G0-2Py, G1-4Py, and G2-8Py afforded complexes with various polymers bearing carboxyl groups by multiple hydrogen bonding. Since multiple hydrogen bonding is potentially reversible by external stimuli, such as temperature, concentration and polarity of solvents, the properties of the complexes may be controlled by the formation or cleavage of multiple hydrogen bonding. In addition, there are little reports on dendrimers bearing pyridine groups at the periphery. Since pyridine groups are also used for coordination bonding in stead of hydrogen bonding, new soft-materials might be prepared.

\section{REFERENCES}

1. R. P. Sijbesma, F. H. Beijer, L. Brunsveld, B. J. B. Folmer, J. H. K. K. Hirschberg, R. F. M. Lange, J. K. L. Lowe, and
E. W. Meijer, Science, 278, 1601 (1997).

2. B. J. B. Folmer, R. P. Sijbesma, and E. W. Meijer, J. Am. Chem. Soc., 123, 2093 (2001).

3. B. J. B. Folmer, R. P. Sijbesma, H. Kooijman, A. L. Spek, and E. W. Meijer, J. Am. Chem. Soc., 121, 9001 (1999).

4. R. F. M. Lange, M. V. Gurp, and E. W. Meijer, J. Polym. Sci., Part A: Polym. Chem., 37, 3657 (1999).

5. C. Fouquey, J. M. Lehn, and A. M. Levelut, Adv. Mater., 2, 254 (1990).

6. T. Kato and J. M. J. Fréchet, Macromolecules, 22, 3818 (1989).

7. T. Kato, H. Kihara, U. Kumar, T. Uryu, and J. M. J. Fréchet, Angew. Chem., Int. Ed., 33, 1644 (1994).

8. T. Kato and J. M. J. Fréchet, Macromol. Symp., 98, 311 (1995).

9. S. Palacin, D. N. Chin, E. E. Simanek, C. J. MacDonald, G. M. Whitesides, M. T. McBridge, and G. T. R. Palmore, J. Am. Chem. Soc., 119, 11807 (1997).

10. E. E. Simanek, L. Isaacs, C. C. C. Wang, and G. M. Whitesides, J. Org. Chem., 62, 8994 (1997).

11. M. Mammen, E. I. Shakhnovich, J. M. Deutch, and G. M. Whitesides, J. Org. Chem., 63, 3821 (1998).

12. I. S. Choi, X. Li, E. E. Simanek, R. Akaba, and G. M. Whitesides, Chem. Mater., 11, 684 (1999).

13. W. Chen, N. J. Turro, and D. A. Tomalia, Langmuir, 16, 15 (2000).

14. M. F. Ottaviani, B. Sacchi, N. J. Turro, W. Chen, S. Jockusch, and D. A. Tomalia, Macromolecules, 32, 2275 (1999).

15. M. F. Ottaviani, F. Furini, A. Casini, N. J. Turro, S. Jockusch, D. A. Tomalia, and L. Messori, Macromolecules, 33, 7842 (2000).

16. V. A. Kabanov, A. B. Zezin, V. B. Rogacheva, Z. G. Gnlyaera, M. F. Zansochova, J. G. H. Joosten, and J. Brackman, Macromolecules, 32, 1904 (1999).

17. V. A. Kabanov, V. G. Sergeyev, O. A. Pyshkina, A. A. Zinchenko, A. B. Zezin, J. G. H. Joosten, J. Brackman, and K. Yoshikawa, Macromolecules, 33, 9587 (2000).

18. H. Zhang, Y. Fu, D. Wang, L. Wang, Z. Wang, and X. Zhang, Langmuir, 19, 8497 (2003).

19. M. Jikei, T. Koketsu, K. Yokomachi, and M. Kakimoto, Polym. Prepr., 44, 581 (2003).

20. Y. Ishida, M. Jikei, and M. Kakimoto, Macromolecules, 33, 3202 (2003).

21. T. G. Fox, Bull. Am. Phys. Soc., 1, 123 (1956). 